\title{
Uterine angioleiomyoma - a rare variant of uterine leiomyoma: review of literature and case reports
}

\author{
Dobrosława L. Sikora-Szczęśniak \\ Department of Obstetrics and Gynaecology, Specialist Hospital in Radom, Poland
}

\begin{abstract}
Introduction: Uterine angioleiomyoma (AL) is an extremely rare variant of uterine leiomyoma. It is composed of smooth muscle cells and thick-walled blood vessels. Angioleiomyoma usually occurs in middle-aged women, 40-60 years old. Aim of the study was to review of literature research reports on uterine AL. Discussion of nine case reports of uterine $\mathrm{AL}$ in the patients operated on in our ward.

Material and methods: The paper presents analysis of accessible research reports on uterine AL, and medical records of the patients operated on in our ward.

Results: Mean age of the patients with uterine AL was $47.11 \pm 5.21$, body mass index (BMI) $25.88 \pm 3.95$. All women had given birth (1-5 natural deliveries, 2.44 mean). Uterine AL occurred in $0.34 \%$ to $0.40 \%$ cases of leiomyomas. Angioleiomyoma were located intramurally and subserosally in six and three patients (respectively, $66.7 \%$ and $33.3 \%)$. Laparotomy was undertaken in seven cases (77.8\%), transvaginal access in two cases (22.2\%), and myomectomy in one case (11.1\%). Blood transfusion was required in four cases (44.4\%).

Conclusions: In the group of uterine leiomyomas, uterine ALs occurred in $0.34-0.40 \%$ of cases. Angioleiomyoma cases posed a greater risk of complications threatening the patient's health and life. Preoperative differentiation of AL with ovarian tumour was more difficult due to frequent degenerative lesions in the course of uterine $\mathrm{AL}$.
\end{abstract}

Key words: uterine angioleiomyoma, surgical operation.

\section{Introduction}

Angioleiomyoma $(\mathrm{AL})$ is a benign tumour of mesenchymal origin. Among uterine leiomyoma variants, $\mathrm{AL}$ in the uterine body is extremely rare [1]. According to a review by Handler et al. only 11 cases of uterine ALs were reported in English language literature in 1966-2007 [2]. Diwaker et al. quoted 15 cases, and Sharma et al. found 16 English language publications on uterine ALs [3, 4].

The aetiology of uterine AL remains unclear. In addition to minor trauma and chronic venous insufficiency, the development of uterine $\mathrm{AL}$ can be affected by sex hormones. Pertinent symptoms of the disease speak for hormone-dependent uterine leiomyoma formation in women on hormone replacement therapy (HRT) in the peri- and postmenopausal period [5].

The researchers also postulate the involvement of angiogenesis. Angioleiomyomas form in the process of angiogenesis when vascular walls thicken due to the proliferation of smooth muscle cells [6, 7]. In addition to the transport of blood, blood vessels are essential to the integrity of the entire body. In that respect vascular endothelial cells responsible for restructuring and angiogenesis are very important $[8,9]$. Generally, uterine $A L$ is composed of primitive thick-walled torturous blood vessels surrounded in a chaotic manner by interlaced spindles of well-differentiated smooth muscle cells arising from venous or arterial walls $[10,11]$.

Contrary to angiogenesis, in arteriogenesis blood vessels form independently of hypoxia. The process is induced by increased shear stress. As a result, "dormant" endothelial cells (ECS) are activated. Growth factors produced by perivascular macrophages transform small collateral vessels into large arteries with diameters 20 times larger [6, 7]. Endothelial cells are essential for the integration of mechanical forces with molecular signals in arteriogenesis [12]. Chemically, arteriogenesis is related to cytokine - basic fibroblast growth factor (bFGF) and angiogenin from the angiopoietin family. Basic fibroblast growth factor encoding gene is located on the short arm of chromosome $4[13,14]$. The cytokine is produced by myocytes, fibroblasts, macrophages, mastocytes, and tumour cells. It is present in the cytoplasm and transported by leukocytes and thrombocytes $[13,15]$. Like plateletderived growth factor (PDGF), bFGF is a myogene for ECs and smooth muscle cells [7]. The endothelium responds to bFGF via tyrosine kinase receptors from the fibroblast growth factor receptor (FGFR) family $[13,15]$. Angiopo- 
etin-1 exhibits paracrine activity, i.e. it induces migration, adhesion, and survival of endothelial cells [16].

Genetic bases of the leiomyoma cell evolution are not well known yet. Auguściak-Duma et al. state that $40 \%$ of those benign tumours present abnormal karyotype [17]. In their search of literature on molecular and cytogenetic origin of leiomyomas, Knapp et al. found that almost $50 \%$ of the tumours presented chromosomal aberrations. Translocation, duplication, and deletion were observed on chromosomes 7, 12, and 14 . However, balanced translocations were seen on chromosomes 12 and 14 [18]. Hennig et al. found cytogenetic clonal changes in the karyotype in uterine $\mathrm{AL}$, which was never spotted in conventional leiomyoma. Cytogenetic analysis of uterine $\mathrm{AL}$ in a 41-year-old patient demonstrated the following karyotype abnormalities: 6,X,t $(X ; 11)(p 11.4 ; p 15) / 46$, idem,inv(2)(p15q13)/46, idem,inv(2)(p15q13),t(5;20)(q13.2) [19].

Microscopically, three histological types were distinguished in AL variant, i.e. capillary of dense structure with narrow vessels interlaced with thick fascicles of smooth muscles, venous type composed of thick vessels interspersed with fascicles of smooth muscles, and cavernous with widened vessels and lesser amount of smooth muscles. In that type vascular muscular walls are difficult to differentiate from intervascular fascicles of smooth muscles [20].

The patients with postoperatively diagnosed uterine ALs usually present with lower abdominal pain and abnormal uterine bleeding. Clinical and radiological differentiation between AL and leiomyoma is difficult [21]. Uterine AL may be suspected preoperatively when imaging scans show signs of vascular damage in patients with uterine bleeding and anaemia [22-24]. In some cases, imaging techniques (USG, CT, MRI) may suggest preoperative diagnosis of uterine $\mathrm{AL}$. The effectiveness of diagnosis is limited to establishing the nature and extent of the lesion [23, 24].

According to many authors, differential preoperative diagnosis of that $A L$ variant with other tumours is extremely difficult, and therefore it is not usually made until microscopic examination has been performed [ 1 , $3,8]$. Differential diagnosis based on histopathological and immunohistochemical findings considers fibroma, angiofibroma, angiolipoma, and angiomyofibroblastoma, which are vimentin- and desmin-positive but smooth muscle actin-(SMA) negative [25]. Perivascular epithelioid cell tumour - PEComa is HMB-45-positive [26].

Immunohistochemical assays use immunoreactivity against SMA, vimentin, desmin, caldesmon, and progesterone receptors. Immunoreactivity of CD10 and oestrogen receptor is weak; however, endothelial cells are CD34- and CD31-reactive.

This paper reviews literature reports on uterine $A L$. In addition, we present uterine AL cases in the patients operated on in our ward over an 18-year period.

\section{Material and methods}

This paper reviews literature reports on uterine angioleiomyoma, a variant of leiomyoma. In addition, medical records of nine patients with postoperative histological diagnosis of uterine ALs were retrospectively analysed.

The patients were qualified for operation on the basis of gynaecological examination, USG, and histological assessment of uterine samples. In one case an operation, i.e. hysterectomy with bilateral appendages, had to be performed on an emergency basis due to the perforation of the uterus at an attempt of diagnostic abrasion. Final diagnoses were made on the basis of postoperative microscopic examinations in the Pathomorphological Laboratory, Regional Specialist Hospital in Radom. In doubtful cases, immunohistochemical assays were done [26].

\section{Results}

Sahu et al., Bommanahalli et al., Laximinarayana et al., Garg et al., Kamath et al., Gómeza et al., Demiray et al., Zizi-Sermpertzoglou et al., Grigoriadis et al., and Lazarov et al., have recently reported on ALs [1, 10, 21, 27-33].

In Polish literature on the subject ALs in the uterine body were discussed in two reports [34, 35]. In general, the authors reported on single cases of uterine AL. Only two reports presented two and three cases of uterine $\operatorname{AL}[36,37]$.

However, Chinese authors presented clinical analysis of 26 and 29 cases of AL [38, 39]. Thomas et al., Hsieh et al., and Hakverdi et al. reported on multiple uterine $A L s[22,40,41]$. The cases of $A L$ in the uterine cervix were presented by Koleskas et al., Al-Sannaa et al., and Ye et al. [42-44].

The analysis of medical records of the patients treated in our ward over an 18-year period (1998-2015) revealed 1413 cases of leiomyomas and 875 leiomyomas with uterine endometriosis. Among 2270 cases of leiomyomas and leiomyomas with uterine endometriosis there were nine cases of leiomyoma angiogenes (0.40\%). Mean age of the patients was 47.11 years, SD \pm 5.21 , the youngest patient was 43 , the oldest was 60 years old. Mean body mass index (BMI) was 25.88, SD \pm 3.95 (20.42-33.59). Three women had BMI <25.0, five women were overweight (BMI 25.0-29.9), and one woman was obese (BMI $\geq 30.0)$. Moreover, there was a case of superpathological obesity noted, class III (BMI = 54.6) [35]. In the examined group the mean number of deliveries was 2.44 (1-5 deliveries); all 22 deliveries were natural.

In the group of AL in the uterine body six were intramural (66.7\%) and three were subserosal (33.3\%).

In the group of patients operated on for uterine $\mathrm{AL}$ the biggest size of the uterus was $180 \times 150 \times 120 \mathrm{~mm}$. The excised masses were $25-100 \mathrm{~mm}$ in diameter; the big- 
gest uterine $\mathrm{AL}$ mass (subserosal, myoma nascens) was $130 \times 50 \times 50 \mathrm{~mm}$.

Other pathologies concomitant to AL included:

- leiomyoma and endometriosis - 1 case,

- multiple leiomyomas - 1 case,

- endometriosis - 2 cases,

- erosion -3 cases,

- thecoma of the right ovary - 1 case,

- paratubal serous cyst -2 cases.

Table I presents information about female patients and types, the results of the treatments and operations performer in cases of uterine angioleiomyoma.

\section{Surgical procedures and operations}

In the majority of cases, surgical management of uterine $\mathrm{AL}$ involved hysterectomy with or without appendages. Myomectomy was rather rare [21, 37, 45].

In the group of nine patients, seven women (77.8\%) had laparotomy performed: in six cases $(66.7 \%)$ hysterectomy (with bilateral appendages - three cases, unilateral - one case, with the right fallopian tube - one case, and without appendages - one case). Myomectomy was performed in one case (11.1\%). Angioleiomyomas in the uterine body were transected from transvaginal access: subserosally located - two cases (22.2\%).
Generally, microscopic examination of AL samplings found no features of atypia, mitosis, pleomorphism, or necrosis. However, the authors presented individual cases of nuclear atypia [1, 37, 40].

Degeneration in angioleiomyoma often results from ischaemia, and the type depends upon the degree and speed of ongoing vascular insufficiency [46]. Mucoid areas, hyalinisation, calcification, and fatty deposits were also noted [1, 10, 22, 40]. Fibryn accumulation in the widened blood vessels of angioleiomyoma was reported, too $[2,18,37,40]$.

The analysis of patients' medical records revealed the following microscopic examination findings:

- hyalinisation - 2 cases,

- swelling and hyalinization - 1 case,

- necrosis and swelling - 1 case,

- ulceration - 1 case (in subserosal angioleiomyoma nascens).

In the cases qualified for differentiation with uterine angioleiomyoma, histopathological examination was necessary [26].

Literature reports present numerous complications posing a serious threat to the health and life of patients with uterine ALs, such as spontaneous rupture of the uterus with bleeding to the peritoneal cavity, and disordered blood clotting due to consumptive coagulopathy $[5,28]$.

Tab. I. Cases of angioleiomyoma uterus found on the ward $(\mathrm{N}=9)$

\begin{tabular}{|c|c|c|c|c|c|c|c|c|}
\hline No. & $\begin{array}{l}\text { Date of } \\
\text { surgery }\end{array}$ & Initials & $\begin{array}{c}\text { Age } \\
\text { [years] }\end{array}$ & $\begin{array}{l}\text { Body mass } \\
\text { (BMI) }\end{array}$ & $\begin{array}{l}\text { Preoperative } \\
\text { diagnosis }\end{array}$ & $\begin{array}{c}\text { Surgery } \\
\text { treatment }\end{array}$ & $\begin{array}{c}\text { Histopathological } \\
\text { diagnosis } \\
\text { angioleiomyoma }\end{array}$ & $\begin{array}{c}\text { Other diseases } \\
\text { genital }\end{array}$ \\
\hline 9 & 17.09.2015 & I.U. & 48 & $\begin{array}{c}59 \\
(20.42)\end{array}$ & Muscles emerging & BUEM & $\begin{array}{l}\text { Angioleiomyoma } \\
\text { submucosa }\end{array}$ & \\
\hline 8 & 12.04 .2014 & D.B. & 44 & $\begin{array}{c}58 \\
(20.55)\end{array}$ & Fibroid uterus & MM & Angioleiomyoma & \\
\hline 7 & 11.12 .2012 & K.N. & 60 & $\begin{array}{c}70 \\
(20.04)\end{array}$ & $\begin{array}{l}\text { Uterine fibroids } \\
\text { Perforation of the } \\
\text { uterus }\end{array}$ & $\mathrm{TAH}+\mathrm{BSO}$ & $\begin{array}{l}\text { Angioleiomyoma } \\
\text { necroticans and } \\
\text { oedematosum }\end{array}$ & $\begin{array}{l}\text { Endometriosis } \\
\text { Endometrial polyp } \\
\text { Thecoma right ovary }\end{array}$ \\
\hline 6 & 10.10 .2012 & M.I. & 43 & $\begin{array}{c}60 \\
(25.97)\end{array}$ & $\begin{array}{l}\text { Fibroids uterus } \\
\text { Cervical erosion }\end{array}$ & $\mathrm{TAH}+\mathrm{RS}$ & $\begin{array}{l}\text { Angioleiomyoma } \\
\text { subserosa }\end{array}$ & $\begin{array}{l}\text { Intramural fibroids } \\
\text { Cyst serous fallopian } \\
\text { right }\end{array}$ \\
\hline 5 & 01.10 .2009 & P.H. & 48 & $\begin{array}{c}86 \\
(33.59)\end{array}$ & Fibroids uterus & $\mathrm{TAH}+\mathrm{RSO}$ & $\begin{array}{l}\text { Angioleiomyoma } \\
\text { submucosa exul- } \\
\text { cerans }\end{array}$ & $\begin{array}{l}\text { Intramural fibroids } \\
\text { Endometriosis }\end{array}$ \\
\hline 4 & 21.08 .2008 & L.H. & 47 & $\begin{array}{c}72 \\
(24.77)\end{array}$ & $\begin{array}{l}\text { Fibroids uterus } \\
\text { Cervical erosion }\end{array}$ & TAH & $\begin{array}{l}\text { Angioleiomyoma } \\
\text { hyalinisans }\end{array}$ & Endometrial polyp \\
\hline 3 & 08.04 .2003 & J.M. & 46 & $\begin{array}{c}60 \\
(26.40)\end{array}$ & $\begin{array}{l}\text { Fibroid uterus } \\
\text { Uterine bleeding }\end{array}$ & BUEM & $\begin{array}{l}\text { Angioleiomyoma } \\
\text { submucosa }\end{array}$ & Endometritis chronic \\
\hline 2 & 02.10 .1998 & S.K. & 43 & $\begin{array}{c}63 \\
(26.56)\end{array}$ & $\begin{array}{l}\text { Many fibroids } \\
\text { endometrial } \\
\text { Cervical erosion } \\
\text { Secondary anaemia }\end{array}$ & $\mathrm{TAH}+\mathrm{BSO}$ & $\begin{array}{l}\text { Angioleiomyoma } \\
\text { intramural oede- } \\
\text { matosum partly } \\
\text { hyalinisans }\end{array}$ & Ovarian follicular cyst \\
\hline 1 & 14.01.1998 & Ś.B. & 45 & $\begin{array}{c}64 \\
(26.64)\end{array}$ & $\begin{array}{l}\text { Fibroids uterus } \\
\text { Cervical erosion }\end{array}$ & $\mathrm{TAH}+\mathrm{BSO}$ & $\begin{array}{l}\text { Angioleiomyoma } \\
\text { hyalinisans }\end{array}$ & $\begin{array}{l}\text { Endometriosis } \\
\text { Endometrial polyp } \\
\text { Ovarian follicular cyst }\end{array}$ \\
\hline
\end{tabular}

TAH - total abdominal hysterectomy, BSO - bilateral salpingo-oophorectomy, MM - myomectomy, RS - rechten salpingectomy, RSO - rechten salpingooophorectomy, BUEM - a biopsy of the cervical canal and the walls of the uterus; evacuation myoma 
Perioperative transfusion of blood and blood products was required in four patients (44.4\%), four units of packed red blood cells (PRBC) in one patient and two units of PRBC in three patients.

The authors generally agree that surgical total removal of angioleiomyoma either by laparotomy or laparoscopy is a sufficient management because no recurrence has been noted so far [21].

In the majority of cases the treatment involved hysterectomy with or without the resection of appendages. Myomectomy was rare, and its decision depended upon the patient's desire to maintain fertility [21, 31, 37, 45].

In one case presented in Polish literature on the subject the patient was operated on twice because the first operation was not total. The recurrence of tumour was diagnosed within a few months following myomectomy. Histopathological examination confirmed that the tumour was not totally removed, and angioleiomyoma was diagnosed. The tumour recurred three years following the second operation and the patient was prescribed radiotherapy [34].

\section{Discussion}

At present the World Health Organization (WHO) does not classify uterine $\mathrm{AL}$ as a separate entity or leiomyoma variant in the group of uterine cancers [1, 4, 30].

McCluggage et al. proposed a motion to the WHO to include angioleiomyoma among benign variants of uterine leiomyomas [37].

In the examined group, ALs in the uterine body were postoperatively diagnosed in $0.40 \%$ cases, and its percentage was higher than that noted in Polish reports on the subject (0.34\%) [35]. In our group the patients' ages ranged from 43 to 69 years, and it was within the age range quoted in most reports, i.e. 30-69 years according to Garg et al. [21].

Koleskas et al. and Ye et al. reported the cases of AL colli uteri with massive bleeding [42, 44].

Moreover, Handler et al., Hsieh et al., and Hakverdi et al. presented cases of multiple angioleiomyoma of the uterine body, too $[2,22,41]$.

The analysis of our material found no such cases.

In case of uterine $A L$, pain results from ischaemia in the $A L$ region due to vascular cramps [22].

Researchers believe that abnormal uterine bleeding, often responsible for anaemia, results from dysregulated growth factors and their receptors, which affect vascular morphology and regulate angiogenesis [22]. Basic fibroblast growth factor is said to play a special role in that pathology $[5,13]$. Culhaci et al. suggested that massive bleeding might be due to hypertension [25]. Those symptoms might be more pronounced in $\mathrm{AL}$ cases compared to leiomyoma $[2,25,28]$. In the examined group as many as $77.8 \%$ patients presented with such complaints.
Literature reports found that angioleiomyoma was associated with several episodes of massive bleeding from the genital organs, causing a severe life and health threat $[4,22,44,47]$.

Handler et al. reported on a rare case of coagulopathy due to large necrotically altered uterine angioleiomyoma [2]. Kamath et al. presented a case of hyperfibrinogenaemia in a patient with uterine $A L$ [28]. Culhaci et al. observed rupture of the uterine body due to angioleiomyoma [25].

In the examined group of nine patients with uterine $\mathrm{AL}$, transfusion of blood and blood products was required in $44.4 \%$ of patients because of post-haemorrhagic anaemia, and that was 5-6 times higher than the percentage noted on obstetric-gynaecological wards in regional and clinical hospitals $(8.2 \%$ and $6.6 \%$, respectively) in patients with uterine leiomyomas [48].

In general, atypia, mitosis, pleomorphism, and necrosis are absent in benign uterine AL. However, there are individual cases of atypia and mitosis reported. Thomas et al. presented atypia in a patient with increased CA-125 and pseudo-Meigis syndrome [40]. Sahu et al. presented a case in which they found focal atypia in addition to mucoid areas and hyalinisation [1]. McCluggage et al. observed a case of mitosis of 2 per 10 high-power fields [37]. In one case the areas of mild cellular atypia and slight increase in mitotic activity, mean 3-4 mitoses per 10 power fields, were observed by Manimekhala et al. [36].

In some cases degeneration in AL mimics ovarian pathology, which makes diagnosis more difficult, especially if the $A L$ is located on the posterior wall of the uterus [28, 36, 41, 46].

Swelling, mucoid lesions, hyalinisation, accumulation of fibrin deposits, and degeneration were also observed in some reports [1, 22, 37, 40].

Mucoid areas and hyalinised degeneration in uterine $\mathrm{AL}$ were reported by Kamath et al., Agorastos et al. [28, 46], and Manimekhala et al. [36].

In the examined group histopathological microscopy of AL samplings found swollen areas, hyalinisation, necrosis, and even ulceration in uterine AL myoma nascens.

The analysis of our material and other reported cases revealed that final diagnosis was made postoperatively only when histopathological investigation was performed [21].

\section{Conclusions}

The analysis of our material found angioleiomyoma variant in $0.34-0.40 \%$ cases of uterine leiomyomas.

Uterine ALs were associated with a larger number of complications in the course of disease, the consequence of which was a high percentage of required transfusions of blood and blood products (44.4\%). 
Degeneration in uterine $\mathrm{AL}$, which is observed frequently, makes preoperative differential diagnosis with ovarian tumour more difficult.

\section{Disclosure}

\section{Author reports no conflict of interest.}

\section{References}

1. Sahu L, Tempe A, Agrawal A. Angioleiomyoma of uterus. J Obstet Gynaecol 2012; 32: 713-714.

2. Handler M, Rezai F, Fless KG, et al. Uterine angioleiomyoma compicaded by consumptive coagulopathy. Gynecol Onkol Case Rep 2012; 2: 89-91.

3. Diwaker P, Pradhan D, Garg G. Uterine angioleiomyoma: a rare variant of uterine leiomyoma - a case report and literatur ereview. J Can Res Ther 2015; 11: 49.

4. Sharma C, Sharma M, Chander B, et al. Angioleiomyoma uterus in a adolescent girl: a highly unusual presentation. J Pediatr Adolesc Gynecol 2014 27: e69-71.

5. Stewart EA, Nowak RA. Leyoma-related bleeding: a classic hypothesis updated for the molecular era. Hum Reprod Update 1996; 2: 295-306.

6. Koerselman J, van der Graaf Y, de Jaegere PP, Grobbee DE. Coronary collaterals: animportant and underexposed aspekt of coronary artery disease. Circulation 2003; 107: 2507-2511.

7. Van Royen N, Piek JJ, Schaper W, et al. Arteriogenesis mechanisms of collateralartery development. J Nucl Cardiol 2001; 8: 687-693.

8. Rajotte D, Arap W, Hagedorn M, et al. Molecular heterogeneity of the vascular endothelium revealed by in vivo phage display. J Clin Invest 1998; 102: 430-437.

9. Browder T, Folkman J, Pirie-Shephard S. The hemostatic system as a regulator of. J Biol Chem 2000; 75: 1521-1524.

10. Bommanahalli BP, Murthy N. Angioleiomyoma: a rare variant of uterinae leiomyoma. NJIRM 2014; 5: 131-132.

11. Walocha JA, Litwin JA, Miodoński AJ. Vascular system of intramural leiomyomata revealed by corrosion casting and scanning electron microscopy. Hum Reprod 2003; 18: 1088-1093.

12. Tabibiazar R, Rockson SG. Angiogenesis and the ischaemic heart. Eur Heart J 2001; 22: 903-918.

13. Mizia-Malarz A. Proangiogenic factors: Vascular-endothelial growth factor (VEGF) and basic fibroblast growth factopr - the characteristics and function. Przew Lek 2008; 65: 353-357.

14. Wierzbowska A, Wrzesień-Kruś A, Robak T. Angiogeneza i jej znaczenie w biologii ostrej białaczki szpikowej. Acta Haematol Pol 2002; 33: 5.

15. Zielonka TM. Angiogenesis. Part II. Modulators regulating neovascularization. Alergia Astma Immunologia 2004; 9: 25-31.

16. Lee PS, Poh KK. Endothelial progenitur cells in cardiovascular diseases. World J Stem Cells 2014; 6: 355-366.

17. Auguściak-Duma A, Sieroń A. Molekularna charakterystyka guzów leiomyoma uteri na przykładzie wybranych składników macierzy pozakomórkowej. Postepy Hig Med Dosw 2008; 62: 148-165.

18. Knapp P, Chabowski A. Molekularne i cytogenetyczne podstawy rozwoju mięśniaków macicy. Postepy Hig Med Dosw 2012; 66: 23-32.

19. Hennig Y, Caselitz J, Stern C, et al. Karyotype evolution in a case of uterine angioleiomyoma. Cancer Genet Cytogenet 1999; 108: 79-80.

20. Matsuyama A, Hisaoka M, Hashimoto H. Angioleiomyoma: a clinicopathological and immunohistochemical re with particular reference to the correlation myopericytoma. Hum Pathol 2007; 38: 645-651.

21. Garg G, Mohanty SK. Uterine angioleiomyoma: a rare variant of uterine leiomyoma. Arch Pathol Lab Med 2014; 138: 1115-1118.

22. Hsieh CH, Lui CC, Huang SC, et al. Multiple uterine angioleiomyomas in a woman persenting with severe menorrhagia. Gynecol Oncol 2003 90: 348-352.

23. An J, Kim HN, Cho YH, et al. Uterine vascular leiomyoma with a fat komponent mimickong angiomyolipoma: a case report. J Wom Med 2010; 3: 130-133.

24. Eley KA, Alroyayamina S, Golding SJ, et al. Angioleiomyoma hard palate: case report and review of the literature and magnetic resonance imaging findings of this rare entity. Oral Surg Oral Med Oral Pathol Oral Radiol 2012; 114: e45-49.

25. Culhaci N, Ozkara E, Yksel H, et al. Spontaneously ruptured uterine angioleiomyoma. Pathol Oncol Res 2006; 12: 50-51.

26. Sikora-Szczęśniak DL. PEComa of the uterus- a case report. Ginekol Pol 2013; 84: 234-236.

27. Laxminarayana B, Miya MA, Venishetty $\mathrm{H}$, et al. Angioleiomyoma of uterus - a rare case report. J Dent Med Scien 2015; 14: 60-63.

28. Kamath MS, Acharya M, Kamath V, et al. J Gynecol Surg 2014; 30: 50-52.

29. Gómeza FJ, Machina PF, Dastib CR. Uterine angioleiomyoma with macrovascular and microvascular histological patterns. Prog Obstet Ginecol 2015; 58: 33-36.

30. Demiray H, Gungorduko K, Aydina O. Uterine angioleiomyoma: case report. J Case Rep 2014; 22: 69-73.

31. Zizi-Sermpetzoglou A, Myoteri D, Arkoumani E, et al. Angioleiomyoma of the uterus: report of a distinctive benign leiomyoma variant. Eur J Gynaecol Oncol 2015; 36: 210-212

32. Grigoriadis C, Androutsopoulos G, Zygouris D, et al. Uterine angioleiomyoma causing severe abnormal uterine bleeding. Clin Exp Obstet Gynecol 2014; 41: 102-104

33. Lazarov N, Lazarov L, Lazarov S. Angioleiomyoma uteri in a female patent with damaged healt condition. Diagnostc and terapeutic difficulties. Akush Ginekol 2011; 50: 54-58.

34. Kowalczyk-Amiko K, Szubert M, Hendzel K, et al. Benign tumours of women genital tract with clinical malignancy. Prz Menopauz 2009; 4: 208-211.

35. Sikora-Szczęśniak DL, Szczęśniak G, Sikora W. Angioleiomyoma - a rare variant of genital myomas: report of two cases. Curr Gynecol Oncol 2013; 11: 74-81.

36. Manimekhala. P, Sumanth K, Ramani D, et al. Uterine angioleiomyomas: a report of 2 cases. JEMDS 2013; 2: 3133-3136.

37. McCluggage WG, Boyde A. Uterine angioleiomyomas: a report of 3 cases of a distinctive benign leiomyoma variant. Int J Surg Pathol 2007; 15 : 262-265.

38. Han XY, Oie MR, Yang KX, et al. Clinical pathologic analysis of 26 cases of uterinae vascular leiomyoma. Chin J Obstet Gynecol Pediatr 2005; 1: 23-26.

39. Yuan $Y$, Tan $Y$, Zhou P, et al. Analysis of 29 cases of rare uterinae angioleiomyoma. Chin J Modern Med 2005; 20: 3162-3163.

40. Sunitha T, Radhakrishnan I, Abraham L, et al. Uterine angioleiomyoma with atypia, raised CA-125 levels, and pseudo-Meigs syndrome: an alarming presentation. Case Rep Pathol 2012; 2012: 519473.

41. Hakverdi S, Dolapçioğlu K, Güngören A, et al. Multiple uterine angioleiomyomas mimicking an ovaria neoplasm: a case report. Eur J Gynaecol Oncol 2009; 30: 592-594.

42. Koleskas D, Karagiannis G, Beukenholdt RW. A case of a cervical angioleiomyoma presenting with menorrhagia and pelvic pain: a common presentation of a rare tumour. J Obstet Gynaecol 2009; 29: 161-163.

43. Al-Sannaa GA, Al-Manea M. Cervical angioleiomyoma. J Obstet Gynaecol 2011; $31: 555$

44. Ye $M Z$, Xue $M$, Cheng $C Z$, et al. A case of Massie vaginal hemorrhage caused by cervical vascular leiomyoma. Mod Med Health 2009; 25: $1927-$ 1929.

45. Jin $\mathrm{CH}$, Yi KW, Kim YS, et al. Uterine angioleiomyoma unusual appearance AT laparoscopy. J Minim Invasive Gynecol 2013; 20: 149-150.

46. Agorastos T, Dinas K, Patsiaoura K, et al. Cystic degenerated angioleiomyoma mimicking ovaria pathology. Acta Obstet Gynecol Scand 2001; 80: 863-865.

47. Byun JH, Choi JH, Kim YO, et al. A case of uterine angioleiomyoma causing severe anemia. Korean J Obstet Gynecol 2008; 51: 1203-1209.

48. Dyląg S, Kucharz EJ. Wykorzystanie krwi jej składników w dwóch oddziałach ginekologiczno-położniczych szpitali województwa śląskiego w latach 1996-2002. Pol Merk Lek 2011; 177: 195-201. 